\title{
Stoichiometry of Antibody Neutralization of Human Immunodeficiency Virus Type 1
}

\author{
Xinzhen Yang, ${ }^{1,2 *}$ Svetla Kurteva, ${ }^{1}$ Sandra Lee, ${ }^{3,4}$ and Joseph Sodroski ${ }^{1,2,5}$ \\ Department of Cancer Immunology and AIDS ${ }^{1}$ and Department of Biostatistical Science, ${ }^{3}$ Dana-Farber Cancer Institute, and \\ Department of Pathology, Division of AIDS, ${ }^{2}$ Harvard Medical School, and Department of Biostatistics ${ }^{4}$ and Department of \\ Immunology and Infectious Diseases, ${ }^{5}$ Harvard School of Public Health, Boston, Massachusetts
}

Received 14 July 2004/Accepted 3 November 2004

\begin{abstract}
The human immunodeficiency virus envelope glycoproteins function as trimers on the viral surface, where they are targeted by neutralizing antibodies. Different monoclonal antibodies neutralize human immunodeficiency virus type 1 (HIV-1) infectivity by binding to structurally and functionally distinct moieties on the envelope glycoprotein trimer. By measuring antibody neutralization of viruses with mixtures of neutralizationsensitive and neutralization-resistant envelope glycoproteins, we demonstrate that the HIV-1 envelope glycoprotein trimer is inactivated by the binding of a single antibody molecule. Virus neutralization requires essentially all of the functional trimers to be occupied by at least one antibody. This model applies to antibodies differing in neutralizing potency and to virus isolates with various neutralization sensitivities. Understanding these requirements for HIV-1 neutralization by antibodies will assist in establishing goals for an effective AIDS vaccine.
\end{abstract}

Virus-neutralizing antibodies represent major components of the protective immune response elicited by vaccines. The global epidemic of AIDS has created an urgent need for a vaccine against the etiologic agent, human immunodeficiency virus type 1 (HIV-1). It is likely that effective AIDS vaccines will need to generate efficient humoral and cellular immune responses $(7,16)$. In animal models of HIV-1 infection of humans, neutralizing antibodies have been shown to contribute to protection from virus infection or disease induction $(33,47$, $49,62)$. The only virus-specific targets on HIV-1 accessible to neutralizing antibodies are the envelope glycoproteins $(7,81)$. The gp120 exterior envelope glycoprotein and the gp41 transmembrane envelope glycoprotein are organized into trimeric complexes on the viral surface. The sequential binding of gp120 to the CD4 receptor and either the CCR5 or CXCR4 coreceptor is thought to trigger conformational changes in gp41 that ultimately result in the fusion of the viral and target cell membranes.

During the course of natural HIV-1 infections, virus-neutralizing antibodies are often generated but the neutralizing titers are often low $(27,37)$. The study of monoclonal antibodies from HIV-1-infected humans or from animals vaccinated with various preparations of HIV-1 envelope glycoproteins has provided information on the viral epitopes recognized by neutralizing antibodies. Most neutralizing antibodies bind the gp120 envelope glycoprotein, which is the major exposed protein on the viral envelope glycoprotein trimer $(29,80)$. The gp120 glycoproteins of various HIV-1 strains have evolved surface-exposed variable loops (V1 to V5) that contribute to the protection of more conserved gp120 structures from neutralizing antibodies $(36,66,80)$. Some of these variable struc-

\footnotetext{
* Corresponding author. Mailing address: Dana-Farber Cancer Institute, JFB-609, 44 Binney St., Boston, MA 02115. Phone: (617) 6324359. Fax: (617) 632-3113. E-mail: Xinzhen_Yang@dfci.harvard.edu.
}

tures, such as the V2 and V3 loops, serve as targets for neutralizing antibodies (61). Antibodies directed against the V3 loop, which determines chemokine receptor choice, can block the binding of gp120 to CCR5 or CXCR4 (54). Neutralization by anti-V3 antibodies, although potent, is often limited in breadth to a small number of HIV-1 strains $(61,76)$. Lesscommon V3 loop-directed antibodies with somewhat greater breadth have also been described $(18,19,65)$.

The more conserved receptor-binding surfaces of the HIV-1 gp120 glycoprotein also represent targets for neutralizing antibodies $(7,80,81)$. The CD4-binding site (CD4BS) antibodies recognize a discontinuous gp120 region that overlaps the binding site for CD4. CD4-induced (CD4i) antibodies bind a highly conserved gp120 element that is critical for the gp120-chemokine receptor interaction. It is thought that the ability of CD4BS and CD4i antibodies to interfere with receptor binding contributes to their neutralizing capability.

Some HIV-1-neutralizing antibodies appear to be elicited only rarely in HIV-1-infected individuals. One of these antibodies, 2G12, recognizes a carbohydrate-dependent epitope on the heavily glycosylated surface of gp120 that is exposed on the assembled envelope glycoprotein trimer $(57,58,74)$. Other rarely elicited antibodies bind a linear gp41 epitope proximal to the viral membrane (43). The precise mechanism by which these antibodies interfere with HIV-1 entry is uncertain.

Different models for the neutralization of various viruses by antibodies have been proposed, ranging from the sufficiency of one antibody to inactivate a virion to the requirement for coverage of the entire virion surface $(9,34,48,60)$. As one of the better-understood examples, the influenza A virus, which is similar in size to HIV-1, has about 200 to 300 envelope glycoprotein spikes per virion and requires an average of $70 \mathrm{immu}-$ noglobulin $\mathrm{G}$ molecules to be neutralized $(1,17,25,69,70,79)$. Understanding the stoichiometric requirements for antibody neutralization of HIV-1 is complicated by the replication defectiveness of the vast majority (greater than 99\%) of HIV-1 
virions $(6,30)$, by the small number of intact envelope glycoprotein trimers per virion $(12,20,30,85)$, by spontaneous and ligand-induced dissociation (shedding) of gp120 from the envelope glycoprotein complexes $(40,50,59)$, and by potential heterogeneity among HIV-1 envelope glycoprotein complexes $(6,21,51)$. For example, each HIV-1 virion has 7 to 14 envelope glycoprotein spikes, and an unknown fraction of these on any given virion are functional $(12,30)$. Therefore, the number of antibody molecules required to neutralize a particular HIV-1 virion must vary considerably depending upon arbitrary factors, such as the age and handling of the virus preparation. For a virus such as HIV-1, more meaningful parameters may be the number of antibody molecules required to inactivate a functional envelope glycoprotein spike and the number of envelope glycoprotein trimers that need to remain functional in the presence of antibody for the retention of virion infectivity.

The heterogeneity and defectiveness of HIV-1 preparations preclude the use of direct measurement of antibody binding to virions to obtain information on neutralization stoichiometry. Instead, approaches that assess the interaction of antibodies with the functional subset of virion envelope glycoprotein complexes are needed to achieve insight into stoichiometric parameters. Schønning and colleagues studied the neutralization of viruses with mixtures of wild-type and mutant envelope glycoproteins and suggested that more than one antibody is required to inactivate the HIV-1 virion (60). The HIV-1 envelope glycoproteins oligomerize soon after synthesis in the endoplasmic reticulum $(15,45,78)$. When related envelope glycoproteins are coexpressed, mixed oligomers (heterotrimers) are formed efficiently. Rigorous biochemical measurements indicate that monomeric hemagglutinin molecules from two different strains of influenza A virus form heterotrimers by random association $(5,64)$. Heterotrimer formation between the envelope glycoproteins of different HIV-1 strains and between those of HIV-1 and HIV-2 has been documented previously $(22,42,56)$. We took advantage of this phenomenon of highly efficient heterotrimer formation to create recombinant HIV-1 with various ratios of closely matched envelope glycoproteins that differed in sensitivity to neutralization by a particular antibody. We then assessed the relative neutralization sensitivities of HIV-1 containing various ratios of neutralization-sensitive and neutralization-resistant envelope glycoproteins. The data were analyzed to determine the number of subunits within the envelope glycoprotein trimer that need to be bound by neutralizing antibodies to inactivate the function of the spike.

\section{MATERIALS AND METHODS}

Plasmids expressing HIV-1 envelope glycoproteins. The wild-type and mutant envelope glycoproteins were expressed from the pSVIIIenv vector. The KpnIBamHI fragments encoding the envelope glycoprotein mutants were inserted into the pSVIIIenv vectors expressing the corresponding wild-type envelope glycoproteins $(23,68)$. The $\mathrm{HXBc} 2$ envelope glycoprotein mutants were derived in previous studies $(10,68,72,75)$. The other mutants were created by the PCR-based QuikChange (Stratagene) protocol. The presence of the desired mutations and the absence of unintended coding changes were confirmed by DNA sequencing of the entire env reading frame. The names of the mutants designate the wild-type amino acid residue in single-letter code, the residue number, and the substituted amino acid. The residue numbering is based upon that of the prototypic $\mathrm{HXBc} 2$ envelope glycoproteins, according to current convention (26). All plasmids expressing wild-type and mutant envelope glycopro- teins from one HIV-1 strain were prepared by using a QIAFilter kit (QIAGEN), quantified, and stored as a set.

Immunoprecipitations. To examine HIV-1 envelope glycoprotein expression, processing, and gp120-gp41 association, $9 \mu \mathrm{g}$ of the pSVIIIenv plasmid was cotransfected with $1 \mu \mathrm{g}$ of a plasmid expressing the HIV-1 Tat protein into 293T cells, by using Lipofectamine reagent (Invitrogen) according to the manufacturer's recommendations. Beginning at approximately $24 \mathrm{~h}$ after transfection, the cells were labeled with $200 \mu \mathrm{Ci}$ of $\left[{ }^{35} \mathrm{~S}\right]$ methionine and $\left[{ }^{35} \mathrm{~S}\right]$ cysteine in methionine- and cysteine-free medium for $24 \mathrm{~h}$. The labeled cells were washed with $5 \mathrm{ml}$ of phosphate-buffered saline (PBS) and stripped from the plates with $10 \mathrm{mM}$ EDTA-PBS. The harvested cells were lysed in $1 \mathrm{ml}$ of lysis buffer $(20 \mathrm{mM}$ Tris-HCI [pH 7.4], $0.5 \mathrm{M} \mathrm{NaCl}, 0.5 \% \mathrm{NP}-40$, and $1 \times$ protease inhibitor cocktail [Pharmacia]) for $30 \mathrm{~min}$ at $4^{\circ} \mathrm{C}$. Cell lysates were collected after clearing the cell debris by centrifugation at 14,000 rpm in an Eppendorf microfuge for $30 \mathrm{~min}$ at $4^{\circ} \mathrm{C}$. For the immunoprecipitations, $400 \mu \mathrm{l}$ of medium or cell lysates was incubated overnight at $4^{\circ} \mathrm{C}$ with $3 \mu \mathrm{l}$ of pooled sera from HIV-1-infected individuals and $50 \mu \mathrm{l}$ of protein A-Sepharose (10\%, in PBS; Pharmacia) that had been preincubated with $5 \%$ bovine serum albumin in PBS. After three washes with 1 $\mathrm{ml}$ of lysis buffer, the beads were boiled for $5 \mathrm{~min}$ in $1 \times$ sodium dodecyl sulfate (SDS)-sample buffer with $2 \% \beta$-mercaptoethanol. The protein samples were then analyzed on SDS- $8 \%$ polyacrylamide gels (Invitrogen) and visualized by autoradiography.

Reporter virus stocks and single-round infection assay. Recombinant HIV-1 encoding firefly luciferase and pseudotyped with the wild-type or mutant envelope glycoproteins was produced as previously described (82). Briefly, 293T cells in 100 -mm-diameter tissue culture dishes were cotransfected by using Lipofectamine reagents (Invitrogen) with $2 \mu \mathrm{g}$ of pSVIIIenv plasmid expressing the HIV-1 envelope glycoprotein variants, $2 \mu \mathrm{g}$ of the pCMV $\Delta \mathrm{P} 1 \Delta$ envpA plasmid expressing the Gag/Pol and Tat proteins of HIV-1, and $6 \mu \mathrm{g}$ of pHIV-1Luc, which contains an HIV-1 vector expressing the luciferase reporter gene. The viral stocks were harvested 2 days later, aliquoted, and stored at $-80^{\circ} \mathrm{C}$. All viral stocks containing the envelope glycoproteins derived from one strain of HIV-1 were prepared as a set. The frequency of neutralization-resistant envelope glycoproteins in the virus preparation is defined as $f_{\mathrm{R}}$, where $f_{\mathrm{R}}$ varies from 0 to 1 . To produce virus stocks with various frequencies $\left(f_{\mathrm{R}}\right)$ of neutralization-resistant envelope glycoproteins, $293 \mathrm{~T}$ cells were transfected as described above except that different ratios of the expressor plasmids for the different envelope glycoproteins were used. For example, 1 and $1 \mu \mathrm{g}, 1.6$ and $0.4 \mu \mathrm{g}$, or 1.8 and $0.2 \mu \mathrm{g}$ of the pSVIIIenv plasmids expressing the neutralization-resistant (R) and neutralization-sensitive (S) envelope glycoproteins were used to achieve $f_{\mathrm{R}}$ values of $0.5,0.8$, and 0.9 , respectively. To minimize the potential for pipetting errors in creating viruses when the $f_{\mathrm{R}}$ values were high, the pSVIIIenv plasmids were first diluted so that pipetting could be performed in the 4- to $20-\mu l$ range in all experiments. Recombinant viral production was measured with a standard reverse transcriptase assay, and all viral stocks had reverse transcriptase levels within $20 \%$ of each other (data not shown).

The infectivities of recombinant viruses were measured by incubation of the viruses with either Cf2Th-CD4/CCR5 cells (for viruses with the ADA and YU2 envelope glycoproteins) or Cf2Th-CD4/CXCR4 cells (for viruses with the $\mathrm{HXBc} 2$ and KB9 envelope glycoproteins). Target cells $\left(6 \times 10^{3}\right.$ cells per well $)$ were seeded into 96-well tissue culture Isoplates (EG\&G Wallac) and cultured for $24 \mathrm{~h}$. Viral stocks and the tissue culture medium used for the dilution were prewarmed to $37^{\circ} \mathrm{C}$, and serial dilutions of the viral stocks were made in a total volume of $400 \mu \mathrm{l}$. After the medium was thoroughly removed from the target cells, $100 \mu \mathrm{l}$ of the diluted virus suspension was added to each well. After $48 \mathrm{~h}$, viral infectivity was quantified by measuring the luciferase activity with a luciferase detection kit (Pharmingen) and an automated luminometer (MicroLumat Plus; EG\&G Berthold). For each sample of diluted virus, three wells of target cells were infected in parallel and the mean value of luciferase activity was used.

Antibodies. The monoclonal antibodies used in this study were previously identified and characterized. F105 (52), b12 (8), 15e (55), and F91 (39) are CD4BS antibodies. The $17 \mathrm{~b}$ and $48 \mathrm{~d}$ antibodies (71) are CD4i antibodies. The 2G12 antibody (75) recognizes a carbohydrate-dependent epitope on the HIV-1 gp120 outer domain. The 1121 antibody (ImmunoDiagnostics, Inc.) recognizes the gp120 V3 variable loop. The 2F5 antibody (43) recognizes an epitope in the HIV-1 gp41 ectodomain near the membrane-spanning region. The antibodies were generously provided by James Robinson (Tulane University), Marshall Posner (Beth Israel Deaconess Medical Center), Herman Katinger (Vienna, Austria), Dennis Burton (Scripps Institute), and Peter Kwong, Richard Wyatt, and John Mascola (Vaccine Research Center, National Institutes of Health).

Neutralization assays. For the neutralization assays, all media, viruses, tubes, and racks were prewarmed to $37^{\circ} \mathrm{C}$. Each antibody was serially diluted in medium so that the final volume was $320 \mu \mathrm{l}$ and the highest antibody concentration, after 
addition of the virus stock, was 20 times the reported concentration of antibody at which $50 \%$ of the virus is neutralized. Next, $80 \mu \mathrm{l}$ of the virus stock was added, and the mixture was vortexed briefly. The virus-antibody mixture was incubated at $37^{\circ} \mathrm{C}$ for $2 \mathrm{~h}$ or, for viruses with the HIV-1 YU2 envelope glycoproteins, for $4 \mathrm{~h}$. The residual infectivities of the viruses were determined in triplicate, by using the single-round infection assay described above. The percentage of residual infectivity (PRI) was defined as the infectivity measured at a given concentration of the antibody divided by the infectivity of the same virus stock in the absence of antibody.

Recombinant viruses containing different ratios $\left(f_{\mathrm{R}}=0,0.5,0.8,0.9\right.$, and 1$)$ of the $\mathrm{R}$ and $\mathrm{S}$ envelope glycoproteins were evaluated as a set for neutralization sensitivity to minimize variables other than the virus stocks themselves. The percentage of neutralization sensitivity $(\% \mathrm{NS})$ at each $f_{\mathrm{R}}$ ratio was calculated by $\left(\mathrm{PRI}_{\mathrm{R}}-\mathrm{PRI}_{\text {mix }}\right) /\left(\mathrm{PRI}_{\mathrm{R}}-\mathrm{PRI}_{\mathrm{S}}\right) \times 100 \%$, where $\mathrm{PRI}_{\mathrm{R}}, \mathrm{PRI}_{\mathrm{S}}$, and $\mathrm{PRI}_{\text {mix }}$ represent the percentages of residual infectivity seen for viruses with $\mathrm{R}$ homotrimers, S homotrimers, and mixtures of $\mathrm{R}$ and $\mathrm{S}$ envelope glycoproteins, respectively. All experiments were performed at least two times with two sets of virus stocks that had been independently generated. The results of single experimental sets that were consistent with those of other experiments with the same antibodyvirus combination were used to test the candidate models, as described below.

Construction of models. Models were created that predict the neutralization sensitivity ( $\% \mathrm{NS})$ of recombinant viruses bearing a given ratio $\left(f_{\mathrm{R}}\right.$, ranging from 0 to 1 ) of neutralization-resistant envelope glycoproteins. Underlying the models were some simplifying assumptions: (i) random mixing of $\mathrm{S}$ and $\mathrm{R}$ envelope glycoproteins occurs to create the functional envelope glycoprotein trimers; (ii) the trimers of differing composition function equivalently to mediate virus entry; (iii) the $\mathrm{S}$ envelope glycoproteins in different contexts are equivalent with respect to accessibility to antibody; and (iv) inactivation of a trimer occurs on an all-ornone basis; i.e., once the requisite number of antibodies are bound, the trimer is completely inactivated and fewer bound antibodies have no effect. Our use of R and $\mathrm{S}$ envelope glycoproteins that are similar in levels of expression, processing, subunit association, and virus entry greatly increases the likelihood that the first three of these assumptions are valid. In other studies (X. Yang, S. Kurteva, X. Ren, S. Lee, and J. Sodroski, submitted for publication), we demonstrated that heterotrimer formation occurred by nearly random association of available monomers when two closely related HIV-1 envelope glycoproteins were coexpressed in cells, providing further justification for the first assumption. After screening a large number of candidate mutants, we selected $\mathrm{R}$ mutants such that the $\mathrm{R}$ viral stock as well as the heterotrimer viral stocks supported virus entry at 40 to $150 \%$ of the levels of the wild-type viral stocks, favoring the validity of the second assumption. To satisfy the third assumption, we performed neutralization assays with increasing amounts of antibodies and used only the data from experiments in which saturating amounts of neutralizing antibodies were present, minimizing the potential contribution of minor, context-dependent differences in the affinities of S subunits for antibody. The validity of the fourth assumption is discussed below in Results.

In the models, $N$ represents the number of antibodies that are sufficient to inactivate an individual envelope glycoprotein trimer. For the ease of presentation, we first consider the candidate models wherein each envelope glycoprotein trimer functions independently to mediate HIV-1 entry. For models in which $N$ $=1$, only the $\mathrm{R}$ homotrimers, which are present at a frequency of $f_{\mathrm{R}}{ }^{3}$, are resistant to neutralization. Therefore, $1-f_{\mathrm{R}}{ }^{3}$ represents the frequency of potentially neutralization-sensitive trimers in the virus stocks. For $N=2$ models, both the $\mathrm{R}$ homotrimers (present at a frequency of $f_{\mathrm{R}}{ }^{3}$ ) and the heterotrimers with two $\mathrm{R}$ subunits [present at a frequency of $3 f_{\mathrm{R}}{ }^{2}\left(1-f_{\mathrm{R}}\right)$ ] are resistant to neutralization; thus, $1-\left[f_{\mathrm{R}}{ }^{3}+3 f_{\mathrm{R}}{ }^{2}\left(1-f_{\mathrm{R}}\right)\right]$ represents the frequency of potentially neutralization-sensitive trimers in the virus stocks. For $N=3$, only the $\mathrm{S}$ homotrimers are sensitive to neutralization, and the expected frequency of such homotrimers is $\left(1-f_{\mathrm{R}}\right)^{3}$.

Cell-cell fusion caused by the influenza virus hemagglutinin is thought to involve the cooperative action of several trimeric complexes $(3,4,14,35,67)$. Although no data addressing this issue for HIV-1 exist, we constructed models that incorporated the possibility that more than one envelope glycoprotein trimer is required to form the functional unit that mediates HIV-1 entry. In constructing such models, we made the simplifying assumption that each functional trimer could combine only with its immediately neighboring functional trimers to form an infectious unit. This model permitted all possible variations of such parameters as size and shape of the functional unit and the internal configuration of trimers within a functional unit. $T$ represents the number of trimers in the functional unit. In general, the frequency of potentially neutralizationsensitive functional units in a virus stock can be represented as [ 1 - (frequency of neutralization-resistant trimers $)^{T}$. For models in which $N=1,2$, or 3 , the frequency of potentially neutralization-sensitive functional units in a viral stock with any given $f_{\mathrm{R}}$ value will then be $\left(1-f_{\mathrm{R}}{ }^{3 T}\right), 1-\left[f_{\mathrm{R}}{ }^{3}+3 f_{\mathrm{R}}{ }^{2}\left(1-f_{\mathrm{R}}\right)\right]^{T}$, or $1-[1$ $\left.-\left(1-f_{\mathrm{R}}\right)^{3}\right]^{T}$, respectively. Note that the simplifying assumption described above influences the predictions of these models only when $T \geq 3$.

In a typical HIV-1 viral stock, less than $0.1 \%$ of the virions are infectious $(6$, 30). Therefore, each HIV-1 virion is very unlikely to contain more than one infectious unit. As a result, the neutralization of an HIV-1 preparation should be directly proportionate to the inactivation of infectious units. The term $\%$ NS is defined as the neutralization sensitivity of a viral stock with a given $f_{\mathrm{R}}$ value relative to that of viruses with $\mathrm{S}$ homotrimers $(\% \mathrm{NS}=100 \%)$ and that of viruses with $\mathrm{R}$ homotrimers $(\% \mathrm{NS}=0 \%)$. For models of $N=1,2$, or 3 , the predicted values of $\% \mathrm{NS}$ are given by $\left(1-f_{\mathrm{R}}{ }^{3 T}\right) \times 100 \%,\left\{1-\left[f_{\mathrm{R}}{ }^{3}+3 f_{\mathrm{R}}{ }^{2}\left(1-f_{\mathrm{R}}\right)\right]^{T}\right\} \times$ $100 \%$, or $\left\{1-\left[1-\left(1-f_{\mathrm{R}}\right)^{3}\right]^{T}\right\} \times 100 \%$, respectively. The overall relationship among $\% \mathrm{NS}, f_{\mathrm{R}}, N$, and $T$ could be summarized as: $\% \mathrm{NS}=\left\{1-\left[f_{\mathrm{R}}{ }^{3}+3 f_{\mathrm{R}}{ }^{2}(1\right.\right.$ $\left.-\mathrm{f}_{\mathrm{R}}\right)(N-1)+3 f_{\mathrm{R}}\left(1-f_{\mathrm{R}}\right)^{2}(N-1)(N-2) / 2-3 f_{\mathrm{R}}{ }^{2}\left(1-f_{\mathrm{R}}\right)(N-1)(N-$ 2) $\left./ 2]^{T}\right\} \times 100$. Resolution of this equation with $N=1,2$, and 3 would result in the above-discussed formulae for the models with three different $N$ values.

The predicted $\%$ NS values for $f_{\mathrm{R}}$ values of $0.5,0.8$, and 0.9 were calculated for models in which $N=1,2$, or 3 and $T$ was an integer ranging from 1 to 72 . The upper value of $T$ was chosen based on the hypothetical maximum number of envelope glycoprotein complexes present on an HIV-1 particle, as predicted by transmission electron microscopic observations (46). Furthermore, this number is consistent with the observed envelope content of simian immunodeficiency virus particles, a highly related lentivirus $(83,85)$.

Data fitting. The observed $\%$ NS values for viruses with $f_{\mathrm{R}}$ values of $0,0.5,0.8$, 0.9 , and 1 were determined by the incubation of virus preparations with differing concentrations of antibody and then the addition of the virus-antibody mixture to target cells. The luciferase activity in the target cells $48 \mathrm{~h}$ later was used to calculate PRI and \%NS values, as described above. To examine the deviation of the observed $\%$ NS values from those predicted by a given model, $\chi^{2}$ values were generated for each set of antibodies and envelope glycoprotein mutants by $\chi^{2}=$ $\Sigma\left(\% \mathrm{NS}_{\text {observed }}-\% \mathrm{NS}_{\text {predicted }}\right)^{2} / \% \mathrm{NS}_{\text {predicted }}$ for $f_{\mathrm{R}}$ values of $0.5,0.8$, and 0.9 . For each set of three $\%$ NS values, there were 2 degrees of freedom. Assuming that the probability for type I error was less than $0.05(\alpha<0.05)$, the cutoff value of $\chi^{2}$ for statistical significance is 5.99. Therefore, candidate models consistent with the experimental data should exhibit $\chi^{2}$ values of less than 5.99 .

To estimate $N$ and $T$ based on the synthesis of all 15 sets of $\%$ NS data collected, a mixed nonlinear regression model was developed by using the \% NS expression described above (2). Let $\% \mathrm{NS}_{\mathrm{ij}}=\left\{1-\left[f_{\mathrm{R}}{ }^{3}+3 f_{\mathrm{R}}{ }^{2}\left(1-f_{\mathrm{R}}\right)(N-1)\right.\right.$ $\left.\left.+3 f_{\mathrm{R}}\left(1-f_{\mathrm{R}}\right)^{2}(N-1)(N-2) / 2-3 f_{\mathrm{R}}^{2}\left(1-f_{\mathrm{R}}\right)(N-1)(N-2) / 2\right]^{T}\right\} \times 100$ $+\mathrm{u}_{\mathrm{i}}+\mathrm{e}_{\mathrm{ij}}$ where $\mathrm{i}=1,2, \ldots, 15$ and $\mathrm{j}=1,2,3 . \% \mathrm{NS}_{\mathrm{ij}}$ represents the ith set of antibody and envelope glycoprotein mutant at the jth $f_{\mathrm{R}}$ level. $N$ and $T$ are fixed-effects parameters, $\mathrm{u}_{\mathrm{i}}$ are the random-effects parameters for the $i$ th set, and $\mathrm{e}_{\mathrm{ij}}$ are the residual errors for the ith set at the $\mathrm{jth} f_{\mathrm{R}}$ level. We further assume that $\mathrm{u}_{\mathrm{i}}$ and $\mathrm{e}_{\mathrm{ij}}$ are independent and that they both follow a normal distribution. This nonlinear regression model was solved for $N$ and $T$ by using an SAS Institute, Inc., procedure, PROC NLMIXED. The Newton-Rhapson method was used as an optimization technique in the computation.

\section{RESULTS}

The envelope glycoproteins of four HIV-1 isolates representing a variety of phenotypes were chosen for study. The passage of primary clinical isolates of HIV-1 in tissue-cultured cell lines often leads to the selection of viruses that are more sensitive to antibody-mediated neutralization (84). The YU2 virus was not propagated in tissue culture before molecular cloning, uses the CCR5 coreceptor, and is extremely resistant to neutralization $(31,32)$. The ADA virus is a typical CCR5using primary isolate and is moderately resistant to neutralization $(11,38)$. The KB9 envelope glycoproteins were derived from the $89.6 \mathrm{HIV}-1$ primary isolate by in vivo passaging in rhesus macaques in the context of a simian-human immunodeficiency virus chimera $(13,23,53)$. The KB9 envelope glycoproteins are moderately resistant to neutralization and can use either CCR5 or CXCR4 as a coreceptor. Finally, the $\mathrm{HXBc} 2$ isolate is a CXCR4-using, laboratory-adapted HIV-1 strain that is very sensitive to neutralizing antibodies (44).

The HIV-1-neutralizing antibodies included in this study can 


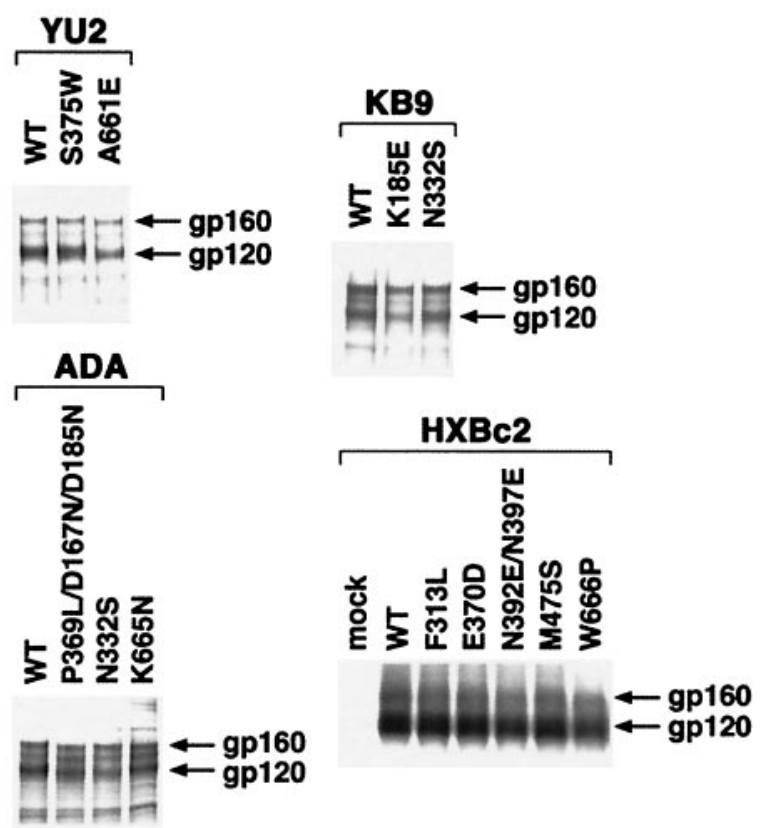

FIG. 1. Expression and processing of HIV-1 envelope glycoprotein variants. 293T cells were transfected with plasmids expressing the wild-type (WT) and mutant envelope glycoproteins from the indicated HIV-1 strains. Radiolabeled cells were then lysed, and the lysates were precipitated with pooled sera from HIV-1-infected individuals, as described in Materials and Methods. The precipitated proteins were analyzed on SDS-8\% polyacrylamide gels. The gp160 envelope glycoprotein precursors and the mature gp120 glycoproteins are indicated.

be grouped into three categories based upon neutralization potency and breadth $(41,73)$. First, 2G12, 2F5, and a CD4BS antibody, b12, potently neutralize diverse clinical isolates of HIV. Second, the V3 loop-directed antibody, 1121, effectively neutralizes a limited number of HIV-1 isolates. Third, the CD4BS antibodies F105, F91, and 15e and the CD4i antibodies $17 \mathrm{~b}$ and $48 \mathrm{~d}$ recognize the gp120 glycoproteins from a broad range of HIV-1 isolates but exhibit only modest neutralization potency.

Mutants deficient in binding the neutralizing antibodies were generated in one or more of the YU2, ADA, KB9, and $\mathrm{HXBc} 2$ envelope glycoproteins, based upon prior mapping of the antibody epitopes. The mutant envelope glycoproteins selected for further study demonstrated levels of expression and processing similar to those of the corresponding wild-type envelope glycoproteins (Fig. 1). Furthermore, the ability of the mutant envelope glycoproteins to support virus entry was at least $40 \%$ of that of the corresponding wild-type glycoproteins (data not shown). The selection of these mutants with phenotypes close to those of the wild-type envelope glycoproteins maximizes the likelihood that the assumptions associated with construction of the neutralization models apply.

Single-round infection assays yield precise quantitative data on the neutralization sensitivity of recombinant HIV-1 with defined envelope glycoproteins, thus providing an opportunity to validate or refute the potential models of neutralization presented above. Recombinant luciferase-expressing viruses with various ratios of $\mathrm{S}$ and $\mathrm{R}$ envelope glycoproteins were produced in transfected cells. By using amounts of plasmid

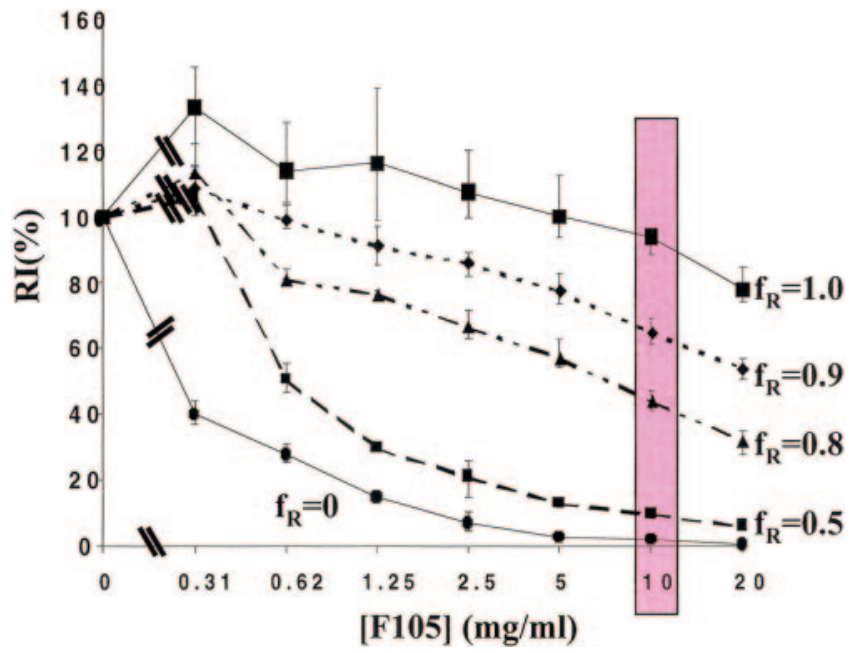

FIG. 2. Neutralization of HIV-1 with HXBc2 envelope glycoproteins by the F105 antibody. Recombinant HIV-1 viruses that express firefly luciferase and contain the wild-type $\mathrm{HXBc} 2$ envelope glycoproteins (neutralization sensitive), the E370D mutant HXBc2 envelope glycoproteins (neutralization resistant), or mixtures of the wild-type and E370D envelope glycoproteins were produced. In the viruses with the mixtures of envelope glycoproteins, the frequency of the E370D envelope glycoproteins $\left(f_{\mathrm{R}}\right)$ was $0.5,0.8$, or 0.9 . Viruses were incubated at $37^{\circ} \mathrm{C}$ for $2 \mathrm{~h}$ with the indicated concentrations of the $\mathrm{F} 105$ antibody, and the virus-antibody mixtures were applied to target cells. The percentage of residual infectivity (RI) represents the luciferase activity observed in the target cells after exposure to antibody relative to that observed in the absence of treatment with antibody. The neutralization sensitivity (\%NS) of the virus stocks was calculated at an F105 concentration of $10 \mu \mathrm{g} / \mathrm{ml}$.

DNA in the linear range of the relationship between transfected DNA and expressed protein, $f_{\mathrm{R}}$ was controlled by varying the relative amounts of plasmids expressing $\mathrm{R}$ and $\mathrm{S}$ glycoproteins. The neutralization sensitivity ( $\% \mathrm{NS})$ of viruses with $f_{\mathrm{R}}$ values of $0,0.5,0.8,0.9$, and 1 was determined by incubation of the virus with differing concentrations of antibody and then adding the virus-antibody mixture to target cells. The luciferase activity in the target cells $48 \mathrm{~h}$ later provided an indication of the basal level of infection in the absence of antibody and the PRI at various antibody concentrations. A typical data set, obtained with the wild-type $\mathrm{HXBc} 2$ and the E370D mutant envelope glycoproteins and the F105 antibody, is shown in Fig. 2. The $\% \mathrm{NS}$ value associated with each $f_{\mathrm{R}}$ ratio was calculated by $\left(\mathrm{PRI}_{\mathrm{R}}-\mathrm{PRI}_{\text {mix }}\right) /\left(\mathrm{PRI}_{\mathrm{R}}-\mathrm{PRI}_{\mathrm{S}}\right) \times 100 \%$, where $P R I_{R}, \mathrm{PRI}_{\mathrm{S}}$ and $\mathrm{PRI} \mathrm{I}_{\text {mix }}$ represent the percentages of residual infectivity seen for the viruses with $R$ homotrimers, $S$ homotrimers, and mixtures of $\mathrm{R}$ and $\mathrm{S}$ envelope glycoproteins, respectively. The \%NS values were calculated at antibody concentrations that resulted in 90 to $99 \%$ neutralization of the viruses with S homotrimers. If two or more sets of data were available, the set associated with the highest level of neutralization was utilized for the calculation of $\% \mathrm{NS}$. This method maximized the possibility of satisfying the model assumption that saturating amounts of antibodies were present to bind all $\mathrm{S}$ subunits in the system. Each experimental set involving a particular envelope glycoprotein mutant and antibody was repeated two to four times, with at least two independently generated sets of viral stocks. 


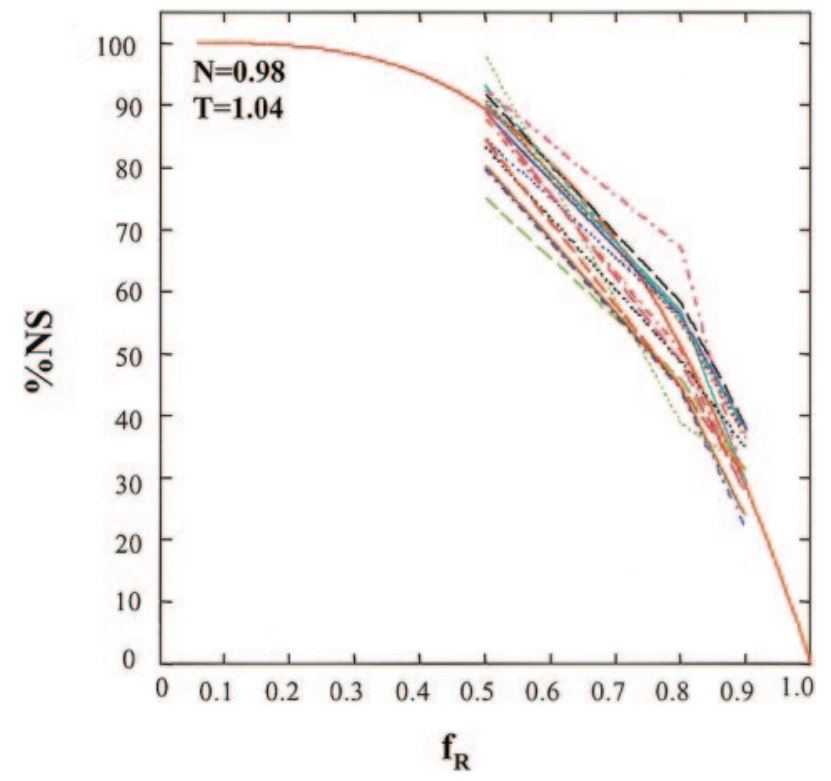

FIG. 3. A mixed nonlinear regression model of the \%NS values derived from 15 sets of antibody and HIV-1 envelope glycoproteins. The solid red line represents the predicted \%NS curve based on the final model with $N=0.98$ (95\% CI, 0.76 to 1.19$)$ and $T=1.04(95 \%$ CI, 0.68 to 1.40). The 15 broken lines represent the 15 sets of observed $\%$ NS values at $f_{\mathrm{R}}=0.5,0.8$, and 0.9 . The necessary convergence of the broken lines to $\% \mathrm{NS}$ values of 100 and 0 at $f_{\mathrm{R}}$ values of 0 and 1 , respectively, is not shown for the sake of clarity.

Theoretical models for the expected neutralization sensitivity of viruses with mixtures of $\mathrm{S}$ and $\mathrm{R}$ envelope glycoproteins were created, using several simplifying assumptions (see Materials and Methods). In the models, $N$ represents the number of antibodies that are sufficient to inactivate an individual envelope glycoprotein trimer, and $T$ represents the number of trimers in the functional unit of neutralization. The $\% \mathrm{NS}$ values predicted by the models are directly related to the frequency of neutralization-sensitive functional units in the virus preparation. Therefore, for models in which $N=1,2$, or 3 , $\% \mathrm{NS}$ is given by $\left(1-f_{\mathrm{R}}{ }^{3 T}\right) \times 100 \%,\left\{1-\left[f_{\mathrm{R}}{ }^{3}+3 f_{\mathrm{R}}{ }^{2}\left(1-f_{\mathrm{R}}\right)\right]^{T}\right\}$ $\times 100 \%$, or $\left\{1-\left[1-\left(1-f_{\mathrm{R}}\right)^{3}\right]^{T}\right\} \times 100 \%$, respectively. The overall relationship among these four parameters could be expressed as: $\% \mathrm{NS}=\left\{1-\left[f_{\mathrm{R}}{ }^{3}+3 f_{\mathrm{R}}{ }^{2}\left(1-f_{\mathrm{R}}\right)(N-1)+\right.\right.$ $3 f_{\mathrm{R}}\left(1-f_{\mathrm{R}}\right)^{2}(N-1)(N-2) / 2-3 f_{\mathrm{R}}^{2}\left(1-f_{\mathrm{R}}\right)(N-1)(N-$ 2)/2] $\left.]^{T}\right\} \times 100$.

By using different combinations of viral envelope strains and neutralizing antibodies, 15 sets of $f_{\mathrm{R}}$ and $\% \mathrm{NS}$ values were generated experimentally (Fig. 3). The observed $\%$ NS values were then modeled as a function of $f_{\mathrm{R}}, N$, and $T$ based on the theoretical relationship established above. Based on this relationship, a mixed nonlinear regression analysis was conducted to parametrically estimate the $N$ and $T$ values involving all 15 sets of the $f_{\mathrm{R}}$ and $\% \mathrm{NS}$ values, by using the SAS PROC NLMIXED procedure. By applying the model relationship to the observed values, the estimated parameter value of $N$ was 0.98 with a $95 \%$ confidence interval (CI) of 0.76 to 1.19 , while the $T$ estimation was 1.04 with a $95 \%$ CI of 0.68 to 1.40 . As 1 was the only integer within the $95 \%$ confidence intervals for $N$ and $T$ estimation, this analysis strongly supports an $N=1 / T=1$ model for the stoichiometry of neutralizing antibody and the HIV-1 envelope glycoprotein trimer.

Each set of the \%NS values from a given combination of antibody and its cognate envelope mutant was also independently fitted to the theoretical values predicted by models with $N$ values of either 1, 2, or 3 and all integral values of $T$ between 1 and 72, the hypothetical maximum for the number of envelope trimers on a virion (46). The fit of the data was calculated by $\chi^{2}=\Sigma\left(\% \mathrm{NS}_{\text {observed }}-\% \mathrm{NS}_{\text {predicted }}\right)^{2} / \% \mathrm{NS}_{\text {predicted }}$. With 2 degrees of freedom, $\chi^{2}$ values greater than 5.99 indicated that the observed distribution of $\%$ NS values was significantly different from that predicted by the model, with the possibility for type I error being less than 5\% $(\alpha<0.05)$. Of the models with different $N$ values, only those in which $N=1$ were consistent with the sets of $\%$ NS values generated for 14 of the 15 antibody-virus combinations (Table 1). Thirteen of the sets of $\%$ NS values could be fitted only with the curves predicted by the $N=1 / T=1$ model and not with those predicted by other models. The observed $\% \mathrm{NS}$ values for the $15 \mathrm{e}$ antibody and viruses with the $\mathrm{HXBc} 2$ envelope glycoproteins were consistent with the $N=1 / T=2$ model but not with other potential models. Of note, for the $N=1 / T=1$ model, the $15 \mathrm{e}-\mathrm{HXBc} 2$ data set had a $\chi^{2}$ value of 6.46 , indicating a probability for type I error between 0.025 and 0.05 ; thus, the lack of fitness of the $N=1 / T=1$ model for this data set is of marginal statistical significance. Because the viral stocks utilized for study of the $15 \mathrm{e}$ antibody were also used to study the $17 \mathrm{~b}$ and $48 \mathrm{~d}$ antibodies, both of which yielded data most consistent with the $N=$ $1 / T=1$ model, the $15 \mathrm{e}-\mathrm{HXBc} 2$ results may be attributed to the nature of the $15 \mathrm{e}$ antibody. The observed data did not fit any model in which $N=1$ and $T \geq 3$; the $\chi^{2}$ values for the $N=1 / T$ $=3$ model were greater than 5.99 for all 15 sets of $\%$ NS data (Table 1), and further increases of the $T$ value resulted in even larger $\chi^{2}$ values (data not shown).

Finally, the $\%$ NS values observed for the 2F5 antibody and viruses with the $\mathrm{HXBc} 2$ envelope glycoproteins did not fit any $N=1$ model, but had $\chi^{2}$ values less than the cutoff for statistical significance for models in which $N=2$ and $T=8$ to 16 (data not shown). Such models seem unrealistic given the average number of envelope glycoprotein spikes on a virion (12, 85 ) and plausible estimates of the number of receptor molecules required for HIV-1 entry (28). The lack of a statistically significant fit of the $2 \mathrm{~F} 5-\mathrm{HXBc} 2$ data to a discrete model suggests that one or more of the assumptions underlying model construction may not have been met in this case. As-yet-undefined properties of the W666P mutant probably account for this, as 2F5 neutralization of viruses with the ADA and YU2 envelope glycoproteins was consistent with an $N=1 / T=1$ model.

\section{DISCUSSION}

Our results indicate that the binding of a single antibody molecule is sufficient to inactivate the functional HIV-1 envelope glycoprotein trimer. This $N=1$ neutralization model was supported by an overall analysis of the relationship between neutralization sensitivity and the frequency of neutralizationresistant envelope glycoprotein trimers for all of the antibodymutant pairs combined. An $N=1$ model was also the only one statistically supported in 14 out of 15 cases when the individual 
TABLE $1 . \% \mathrm{NS}$ and $\chi^{2}$ values for envelope glycoprotein variants and antibodies ${ }^{a}$

\begin{tabular}{|c|c|c|c|c|c|c|c|}
\hline \multirow{2}{*}{$\begin{array}{l}\text { HIV-1 strain and envelope } \\
\text { glycoprotein mutant }\end{array}$} & \multirow{2}{*}{ Antibody } & \multicolumn{3}{|c|}{$\% \mathrm{NS}$ for $f_{\mathrm{R}}$ of: } & \multicolumn{3}{|c|}{$\chi^{2}$ for: } \\
\hline & & 0.5 & 0.8 & 0.9 & $N=1 / T=1$ & $N=1 / T=2$ & $N=1 / T=3$ \\
\hline \multicolumn{8}{|l|}{ YU2 } \\
\hline S375W & b12 & 84.0 & 44.5 & 30.2 & 0.87 & $19.7^{*}$ & $23.0^{*}$ \\
\hline A661E & $2 \mathrm{~F} 5$ & 79.4 & 44.1 & 21.9 & 2.20 & $29.0^{*}$ & $40.2^{*}$ \\
\hline \multicolumn{8}{|l|}{ ADA } \\
\hline P369L/D167N/D185N & b12 & 97.7 & 38.6 & 31.4 & 4.00 & $21.9^{*}$ & $22.3^{*}$ \\
\hline N332S & $2 \mathrm{G} 12$ & 88.8 & 48.6 & 27.6 & 0.03 & $17.5^{*}$ & $28.1^{*}$ \\
\hline K665N & $2 \mathrm{~F} 5$ & 92.7 & 55.5 & 37.6 & 5.30 & $6.71^{*}$ & $22.7^{*}$ \\
\hline \multicolumn{8}{|l|}{ KB9 } \\
\hline K185E & b12 & 80.0 & 44.6 & 23.8 & 1.41 & $26.4^{*}$ & $18.8^{*}$ \\
\hline N332S & $2 \mathrm{G} 12$ & 83.0 & 48.5 & 34.7 & 2.36 & $14.3^{*}$ & $35.2^{*}$ \\
\hline \multicolumn{8}{|l|}{$\mathrm{HXBc} 2$} \\
\hline F313L & 1121 & 84.4 & 55.8 & 36.9 & 4.66 & $8.51^{*}$ & $21.1^{*}$ \\
\hline N392E/N397E & 2G12 & 74.9 & 45.8 & 31.2 & 2.62 & $21.5^{*}$ & $41.2 *$ \\
\hline W666P & $2 \mathrm{~F} 5$ & 92.3 & 67.0 & 28.7 & $7.15^{*}$ & $8.07^{*}$ & $36.4^{*}$ \\
\hline E370D & F105 & 90.0 & 56.7 & 29.2 & 1.51 & $11.4^{*}$ & $20.8^{*}$ \\
\hline E370D & F91 & 90.6 & 55.0 & 36.2 & 3.95 & $7.85^{*}$ & $47.3^{*}$ \\
\hline M475S & $15 \mathrm{e}$ & 91.5 & 58.0 & 38.2 & $6.46^{*}$ & 5.48 & $31.1^{*}$ \\
\hline M475S & $17 \mathrm{~b}$ & 87.6 & 50.5 & 27.5 & 0.07 & $16.57^{*}$ & $38.7^{*}$ \\
\hline M475S & $48 \mathrm{~d}$ & 88.7 & 56.0 & 37.7 & 5.22 & $7.05^{*}$ & $50.4^{*}$ \\
\hline
\end{tabular}

${ }^{a}$ The cutoff for the $\chi^{2}$ value is 5.99, assuming $P<0.05$ for a type I error with 2 degrees of freedom. A $\chi^{2}$ value larger than 5.99 indicates a statistically significant difference between the distribution of observed \%NS data and those predicted by the indicated models. Models that fail to explain the observed \% NS data by this criterion are indicated by an asterisk.

data sets were fit to models with open $N$ and $T$ values. The $N$ $=1$ neutralization stoichiometry is shared by all nine monoclonal antibodies studied in this report; these antibodies exhibit a range of neutralization potencies and bind distinct elements on gp120 or gp41. Thus, once bound to the viral envelope glycoproteins, the inhibitory effect of these antibodies on HIV-1 entry is equivalent. The envelope glycoprotein trimers of neutralization-resistant primary HIV-1 isolates are as susceptible to inactivation by bound antibody as the trimers of more neutralization-sensitive isolates. These observations imply that the major determinant of neutralization potency and susceptibility is the efficiency with which a neutralizing antibody binds to the functional envelope glycoprotein trimer. This conclusion is consistent with the correlation between the HIV-1-neutralizing potency of antibodies and affinity for envelope glycoprotein complexes on the surface of virus-infected cells (63). Immunochemical studies of the influenza A virus indicate that a hemagglutinin trimer can bind only a single antibody molecule in solution even when multiple antibodies with different binding epitopes are available, consistent with an $N=1$ binding stoichiometry (70). In the case of influenza A virus, the high density of envelope glycoprotein spikes on the virion surface may limit the number of antibodies that can simultaneously access a single trimer. It is unknown whether similar considerations would apply to HIV-1, where envelope glycoprotein spike density is low. Soluble simian immunodeficiency virus envelope glycoprotein trimers can bind the Fab fragments of both neutralizing and nonneutralizing antibodies at ratios of $1: 1,1: 2$, or $1: 3$ in solution (24), but the interaction of whole immunoglobulin molecules with infectious virions is less amenable to study.

Another implication of the $N=1$ stoichiometry of HIV-1 neutralization is that binding of two or more antibody mole- cules to the HIV-1 envelope glycoprotein trimer is ultimately no more effective in achieving neutralization than the binding of a single antibody. Thus, synergy among HIV-1-neutralizing antibodies is expected to be modest, consistent with recent observations $(77,86)$. By similar reasoning, minimal negative cooperativity in antibody neutralization of HIV-1 is predicted by the $N=1$ model.

The use of neutralization-resistant and neutralization-sensitive HIV-1 envelope glycoproteins that are closely matched in expression level, precursor processing, subunit association, and ability to support virus entry justifies some of the assumptions inherent in our construction of models (see Materials and Methods). Moreover, given the observed data, violation of several of these underlying assumptions would not alter our conclusion that $N=1$. Lack of or partial mixing of the $\mathrm{S}$ and $\mathrm{R}$ envelope glycoproteins, partial inactivation of envelope glycoprotein trimers by antibody, and segregation of multiple infectious units onto single HIV-1 virions would all predispose towards an overestimation of the value of $N$. Obviously, because $N$ must be an integer greater than zero, our conclusion that $N=1$ cannot be an overestimate.

For 13 of the 14 data sets that supported a discrete model and for the data analyzed collectively, the size $(T)$ of the neutralization target was 1 . The size of the neutralization target $(T)$ is related to, but not necessarily identical with, the number of envelope glycoprotein trimers that cooperate to mediate virus entry. Because antibody-mediated neutralization is hypothetically reversible, $T$ may underestimate the number of trimers needed to allow successful infection. Nonetheless, at the high antibody concentrations used to make our calculation, these two values should be similar, implying that very few envelope glycoprotein trimers are required for HIV-1 entry. Previous estimates of four to five CCR5 receptors cooperating 
to support HIV-1 infection are consistent with this notion (28). Importantly, this result is consistent with our recent studies on the entry stoichiometry of HIV-1 envelope glycoprotein trimers, in which the value of $T$ for viral entry was estimated to be 1 and virions with a single wild-type envelope homotrimer were found to be infectious (Yang et al., submitted). Taken together, these data support a model in which each envelope glycoprotein trimer supports HIV-1 entry independently.

The $N=1 / T=1$ neutralization stoichiometry means that although each envelope trimer needs to bind only one neutralizing antibody to be inactivated, essentially every functional envelope glycoprotein trimer must be bound by an antibody molecule for neutralization of the virus to be achieved. Depending upon the number of functional envelope glycoprotein complexes on a given virion and the number of nonfunctional envelope glycoproteins competing for antibody, the absolute number of bound antibodies required to neutralize that particle may vary. Our results establish well-defined goals for the generation of antibody responses by a prophylactic AIDS vaccine. Antibodies that efficiently bind functional HIV-1 envelope glycoprotein trimers, particularly those that are directed against more conserved epitopes, are desirable. Theoretically, the antibodies elicited by a successful vaccine will, collectively, need to occupy essentially every functional trimer on the challenge viruses to achieve sterilizing immunity. Our results also suggest that partial immunity might be possible because the loss of infectivity of the invading viruses should be proportional to the functional envelope glycoproteins bound by the antibodies. Appreciation of these goals should focus and expedite efforts to create a practical HIV-1 vaccine.

\section{ACKNOWLEDGMENTS}

We thank Y. McLaughlin and S. Farnum for manuscript preparation and J. Robinson, D. Burton, M. Posner, H. Katinger, P. D. Kwong, R. Wyatt, and J. Mascola for antibodies.

This work was supported by grants from NIH (AI24755, AI31783, AI46725) and a Center for AIDS Research award, the International AIDS Vaccine Initiative, the Bristol-Myers Squibb Foundation, and a gift from William F. McCarty-Cooper.

\section{REFERENCES}

1. Amano, H., and Y. Hosaka. 1992. Morphological estimation of total number of influenza A type virion spikes. J. Electron Microsc. 41:104-106.

2. Bard, Y. 1974. Nonlinear parameter estimation. Academic Press, New York, N.Y.

3. Bentz, J. 2000. Minimal aggregate size and minimal fusion unit for the first fusion pore of influenza hemagglutinin-mediated membrane fusion. Biophys. J. 78:227-245.

4. Blumenthal, R., D. P. Sarkar, S. Durell, D. E. Howard, and S. J. Morris. 1996. Dilation of the influenza hemagglutinin fusion pore revealed by the kinetics of individual cell-cell fusion events. J. Cell Biol. 135:63-71.

5. Boulay, F., R. W. Doms, R. G. Webster, and A. Helenius. 1988. Posttranslational oligomerization and cooperative acid activation of fixed influenza hemagglutinin trimers. J. Cell Biol. 106:629-639.

6. Bourinbaiar, A. S. 1994. The ratio of defective HIV-1 particles to replication-competent infectious virions. Acta Virol. 38:59-61.

7. Burton, D. R., R. C. Desrosiers, R. W. Doms, W. C. Koff, P. D. Kwong, J. P. Moore, G. J. Nabel, J. Sodroski, I. A. Wilson, and R. T. Wyatt. 2004. HIV vaccine design and the neutralizing antibody problem. Nat. Immunol. 5:233236.

8. Burton, D. R., J. Pyati, R. Koduri, S. J. Sharp, G. B. Thornton, P. W. Parren, L. S. Sawyer, R. M. Hendry, N. Dunlop, and P. L. Nara. 1994. Efficien neutralization of primary isolates of HIV-1 by a recombinant human monoclonal antibody. Science 266:1024-1027.

9. Burton, D. R., E. O. Saphire, and P. W. Parren. 2001. A model for neutralization of viruses based on antibody coating of the virion surface. Curr. Top. Microbiol. Immunol. 260:109-143.

10. Cao, J., L. Bergeron, E. Helseth, M. Thali, H. Repke, and J. Sodroski. 1993.
Effects of amino acid changes in the extracellular domain of the human immunodeficiency virus type $1 \mathrm{gp} 41$ envelope glycoprotein. J. Virol. 67:27472755 .

11. Cecilia, D., V. N. KewalRamani, J. O’Leary, B. Volsky, P. Nyambi, S. Burda, S. Xu, D. R. Littman, and S. Zolla-Pazner. 1998. Neutralization profiles of primary human immunodeficiency virus type 1 isolates in the context of coreceptor usage. J. Virol. 72:6988-6996.

12. Chertova, E., J. W. Bess Jr., Jr., B. J. Crise, I. R. Sowder, T. M. Schaden, J. M. Hilburn, J. A. Hoxie, R. E. Benveniste, J. D. Lifson, L. E. Henderson, and L. O. Arthur. 2002. Envelope glycoprotein incorporation, not shedding of surface envelope glycoprotein (gp120/SU), is the primary determinant of SU content of purified human immunodeficiency virus type 1 and simian immunodeficiency virus. J. Virol. 76:5315-5325.

13. Crawford, J. M., P. L. Earl, B. Moss, K. A. Reimann, M. S. Wyand, K. H. Manson, M. Bilska, J. T. Zhou, C. D. Pauza, P. W. Parren, D. R. Burton, J. G. Sodroski, N. L. Letvin, and D. C. Montefiori. 1999. Characterization of primary isolate-like variants of simian-human immunodeficiency virus. J. Virol. 73:10199-10207.

14. Danieli, T., S. L. Pelletier, Y. I. Henis, and J. M. White. 1996. Membrane fusion mediated by the influenza virus hemagglutinin requires the concerted action of at least three hemagglutinin trimers. J. Cell Biol. 133:559-569.

15. Earl, P. L., B. Moss, and R. W. Doms. 1991. Folding, interaction with GRP78-BiP, assembly, and transport of the human immunodeficiency virus type 1 envelope protein. J. Virol. 65:2047-2055.

16. Emini, E. A., and W. C. Koff. 2004. AIDS/HIV. Developing an AIDS vaccine: need, uncertainty, hope. Science 304:1913-1914.

17. Gentile, M., T. Adrian, A. Scheidler, M. Ewald, F. Dianzani, G. Pauli, and H. R. Gelderblom. 1994. Determination of the size of HIV using adenovirus type 2 as an internal length marker. J. Virol. Methods 48:43-52.

18. Gorny, M. K., T. C. VanCott, C. Hioe, Z. R. Israel, N. L. Michael, A. J. Conley, C. Williams, J. A. Kessler II, P. Chigurupati, S. Burda, and S. Zolla-Pazner. 1997. Human monoclonal antibodies to the V3 loop of HIV-1 with intra- and interclade cross-reactivity. J. Immunol. 159:5114-5122.

19. Gorny, M. K., C. Williams, B. Volsky, K. Revesz, S. Cohen, V. R. Polonis, W. J. Honnen, S. C. Kayman, C. Krachmarov, A. Pinter, and S. ZollaPazner. 2002. Human monoclonal antibodies specific for conformation-sensitive epitopes of V3 neutralize human immunodeficiency virus type 1 primary isolates from various clades. J. Virol. 76:9035-9045.

20. Hart, T. K., A. M. Klinkner, J. Ventre, and P. J. Bugelski. 1993. Morphometric analysis of envelope glycoprotein gp120 distribution on HIV-1 virions J. Histochem. Cytochem. 41:265-271.

21. Herrera, C., C. Spenlehauer, M. S. Fung, D. R. Burton, S. Beddows, and J. P. Moore. 2003. Nonneutralizing antibodies to the CD4-binding site on the gp120 subunit of human immunodeficiency virus type 1 do not interfere with the activity of a neutralizing antibody against the same site. J. Virol. 77:1084 1091.

22. Iwatani, Y., K. Kawano, T. Ueno, M. Tanaka, A. Ishimoto, M. Ito, and H. Sakai. 2001. Analysis of dominant-negative effects of mutant Env proteins of human immunodeficiency virus type 1 . Virology 286:45-53.

23. Karlsson, G. B., M. Halloran, J. Li, I. W. Park, R. Gomila, K. A. Reimann, M. K. Axthelm, S. A. Iliff, N. L. Letvin, and J. Sodroski. 1997. Characterization of molecularly cloned simian-human immunodeficiency viruses causing rapid $\mathrm{CD}^{+}$lymphocyte depletion in rhesus monkeys. J. Virol. 71:42184225 .

24. Kim, M., B. Chen, R. E. Hussey, Y. Chishti, D. Montefiori, J. A. Hoxie, O. Byron, G. Campbell, S. C. Harrison, and E. L. Reinherz. 2001. The stoichiometry of trimeric SIV glycoprotein interaction with CD4 differs from that of anti-envelope antibody Fab fragments. J. Biol. Chem. 276:42667-42676.

25. Knossow, M., M. Gaudier, A. Douglas, B. Barrere, T. Bizebard, C. Barbey, B. Gigant, and J. J. Skehel. 2002. Mechanism of neutralization of influenza virus infectivity by antibodies. Virology 302:294-298.

26. Korber, B. F., F. Kuiken, C. Pillai, S. Sodroski, J. 1998. Numbering position in HIV relative to HXBc2. In B. K. Korber, C. Foley, F. Hahn, B. Mc Cutchan, F. Mellor, and J. Sodroski (ed.), Human retroviruses and AIDS Los Alamos National Laboratories, Los Alamos, N.Mex.

27. Kostrikis, L. G., Y. Cao, H. Ngai, J. P. Moore, and D. D. Ho. 1996. Quantitative analysis of serum neutralization of human immunodeficiency virus type 1 from subtypes A, B, C, D, E, F, and I: lack of direct correlation between neutralization serotypes and genetic subtypes and evidence for prevalent serum-dependent infectivity enhancement. J. Virol. 70:445-458.

28. Kuhmann, S. E., E. J. Platt, S. L. Kozak, and D. Kabat. 2000. Cooperation of multiple CCR5 coreceptors is required for infections by human immunodeficiency virus type 1. J. Virol. 74:7005-7015.

29. Kwong, P. D., R. Wyatt, Q. J. Sattentau, J. Sodroski, and W. A. Hendrickson. 2000. Oligomeric modeling and electrostatic analysis of the gp120 envelope glycoprotein of human immunodeficiency virus. J. Virol. 74:1961-1972.

30. Layne, S. P., M. J. Merges, M. Dembo, J. L. Spouge, S. R. Conley, J. P. Moore, J. L. Raina, H. Renz, H. R. Gelderblom, and P. L. Nara. 1992 Factors underlying spontaneous inactivation and susceptibility to neutralization of human immunodeficiency virus. Virology 189:695-714.

31. Li, Y., H. Hui, C. J. Burgess, R. W. Price, P. M. Sharp, B. H. Hahn, and G. M. Shaw. 1992. Complete nucleotide sequence, genome organization, and 
biological properties of human immunodeficiency virus type 1 in vivo: evidence for limited defectiveness and complementation. J. Virol. 66:65876600 .

32. Li, Y., J. C. Kappes, J. A. Conway, R. W. Price, G. M. Shaw, and B. H. Hahn. 1991. Molecular characterization of human immunodeficiency virus type 1 cloned directly from uncultured human brain tissue: identification of replication-competent and -defective viral genomes. J. Virol. 65:3973-3985.

33. Mascola, J. R., M. G. Lewis, G. Stiegler, D. Harris, T. C. VanCott, D. Hayes, M. K. Louder, C. R. Brown, C. V. Sapan, S. S. Frankel, Y. Lu, M. L. Robb, H. Katinger, and D. L. Birx. 1999. Protection of macaques against pathogenic simian/human immunodeficiency virus $89.6 \mathrm{PD}$ by passive transfer of neutralizing antibodies. J. Virol. 73:4009-4018.

34. McLain, L., and N. J. Dimmock. 1994. Single- and multi-hit kinetics of immunoglobulin $\mathrm{G}$ neutralization of human immunodeficiency virus type 1 by monoclonal antibodies. J. Gen. Virol. 75:1457-1460

35. Melikyan, G. B, W. D. Niles, and F, S. Cohen. 1995. The fusion kinetics of influenza hemagglutinin expressing cells to planar bilayer membranes is affected by HA density and host cell surface. J. Gen. Physiol. 106:783-802.

36. Modrow, S., B. H. Hahn, G. M. Shaw, R. C. Gallo, F. Wong-Staal, and H. Wolf. 1987. Computer-assisted analysis of envelope protein sequences of seven human immunodeficiency virus isolates: prediction of antigenic epitopes in conserved and variable regions. J. Virol. 61:570-578.

37. Moog, C., H. J. Fleury, I. Pellegrin, A. Kirn, and A. M. Aubertin. 1997 Autologous and heterologous neutralizing antibody responses following initial seroconversion in human immunodeficiency virus type 1-infected individuals. J. Virol. 71:3734-3741.

38. Moore, J., and A. Trkola. 1997. HIV type 1 coreceptors, neutralization serotypes, and vaccine development. AIDS Res. Hum. Retrovir. 13:733-736.

39. Moore, J. P., F. E. McCutchan, S. W. Poon, J. Mascola, J. Liu, Y. Cao, and D. D. Ho. 1994. Exploration of antigenic variation in gp120 from clades A through $\mathrm{F}$ of human immunodeficiency virus type 1 by using monoclonal antibodies. J. Virol. 68:8350-8364.

40. Moore, J. P., J. A. McKeating, R. A. Weiss, and Q. J. Sattentau. 1990 Dissociation of gp120 from HIV-1 virions induced by soluble CD4. Science 250:1139-1142.

41. Moore, J. P., and J. Sodroski. 1996. Antibody cross-competition analysis of the human immunodeficiency virus type 1 gp120 exterior envelope glycoprotein. J. Virol. 70:1863-1872

42. Morikawa, Y., E. Barsov, and I. Jones. 1993. Legitimate and illegitimate cleavage of human immunodeficiency virus glycoproteins by furin. J. Virol. 67:3601-3604

43. Muster, T., F. Steindl, M. Purtscher, A. Trkola, A. Klima, G. Himmler, F. Ruker, and H. Katinger. 1993. A conserved neutralizing epitope on gp41 of human immunodeficiency virus type 1. J. Virol. 67:6642-6647.

44. Oberlin, E., A. Amara, F. Bachelerie, C. Bessia, J. L. Virelizier, F. ArenzanaSeisdedos, O. Schwartz, J. M. Heard, I. Clark-Lewis, D. F. Legler, M Loetscher, M. Baggiolini, and B. Moser. 1996. The CXC chemokine SDF-1 is the ligand for LESTR/fusin and prevents infection by T-cell-line-adapted HIV-1. Nature 382:833-835.

45. Otteken, A., P. L. Earl, and B. Moss. 1996. Folding, assembly, and intracellular trafficking of the human immunodeficiency virus type 1 envelope glycoprotein analyzed with monoclonal antibodies recognizing maturational intermediates. J. Virol. 70:3407-3415.

46. Ozel, M., G. Pauli, and H. R. Gelderblom. 1988. The organization of the envelope projections on the surface of HIV. Arch. Virol. 100:255-266.

47. Parren, P. W., P. A. Marx, A. J. Hessell, A. Luckay, J. Harouse, C. ChengMayer, J. P. Moore, and D. R. Burton. 2001. Antibody protects macaques against vaginal challenge with a pathogenic R5 simian/human immunodeficiency virus at serum levels giving complete neutralization in vitro. J. Virol 75:8340-8347.

48. Parren, P. W., I. Mondor, D. Naniche, H. J. Ditzel, P. J. Klasse, D. R Burton, and Q. J. Sattentau. 1998. Neutralization of human immunodeficiency virus type 1 by antibody to gp120 is determined primarily by occupancy of sites on the virion irrespective of epitope specificity. J. Virol. 72:3512-3519.

49. Parren, P. W., M. Wang, A. Trkola, J. M. Binley, M. Purtscher, H. Katinger, J. P. Moore, and D. R. Burton. 1998. Antibody neutralization-resistant primary isolates of human immunodeficiency virus type 1. J. Virol. 72:1027010274.

50. Poignard, P., T. Fouts, D. Naniche, J. P. Moore, and Q. J. Sattentau. 1996 Neutralizing antibodies to human immunodeficiency virus type-1 gp120 induce envelope glycoprotein subunit dissociation. J. Exp. Med. 183:473-484

51. Poignard, P., M. Moulard, E. Golez, V. Vivona, M. Franti, S. Venturini, M. Wang, P. W. Parren, and D. R. Burton. 2003. Heterogeneity of envelope molecules expressed on primary human immunodeficiency virus type 1 particles as probed by the binding of neutralizing and nonneutralizing antibodies. J. Virol. 77:353-365.

52. Posner, M. R., L. A. Cavacini, C. L. Emes, J. Power, and R. Byrn. 1993 Neutralization of HIV-1 by F105, a human monoclonal antibody to the CD4 binding site of gp120. J. Acquir. Immune Defic. Syndr. 6:7-14.

53. Reimann, K. A., A. Watson, P. J. Dailey, W. Lin, C. I. Lord, T. D. Steenbeke, R. A. Parker, M. K. Axthelm, and G. B. Karlsson. 1999. Viral burden and disease progression in rhesus monkeys infected with chimeric simian-human immunodeficiency viruses. Virology 256:15-21.

54. Rizzuto, C., and J. Sodroski. 2000. Fine definition of a conserved CCR5binding region on the human immunodeficiency virus type 1 glycoprotein 120. AIDS Res. Hum. Retrovir. 16:741-749.

55. Robinson, J. E., D. Holton, S. Pacheco-Morell, J. Liu, and H. McMurdo. 1990. Identification of conserved and variant epitopes of human immunodeficiency virus type 1 (HIV-1) gp120 by human monoclonal antibodies produced by EBV-transformed cell lines. AIDS Res. Hum. Retrovir. 6:567579

56. Salzwedel, K., and E. A. Berger. 2000. Cooperative subunit interactions within the oligomeric envelope glycoprotein of HIV-1: functional complementation of specific defects in gp120 and gp41. Proc. Natl. Acad. Sci. USA 97:12794-12799.

57. Sanders, R. W., M. Venturi, L. Schiffner, R. Kalyanaraman, H. Katinger, K. O. Lloyd, P. D. Kwong, and J. P. Moore. 2002. The mannose-dependent epitope for neutralizing antibody 2 G12 on human immunodeficiency virus type 1 glycoprotein gp120. J. Virol. 76:7293-7305.

58. Scanlan, C. N., R. Pantophlet, M. R. Wormald, E. Ollmann Saphire, R. Stanfield, I. A. Wilson, H. Katinger, R. A. Dwek, P. M. Rudd, and D. R. Burton. 2002. The broadly neutralizing anti-human immunodeficiency virus type 1 antibody 2 G12 recognizes a cluster of alpha $1 \rightarrow 2$ mannose residues on the outer face of gp120. J. Virol. 76:7306-7321.

59. Schneider, J., O. Kaaden, T. D. Copeland, S. Oroszlan, and G. Hunsmann. 1986. Shedding and interspecies type sero-reactivity of the envelope glycopolypeptide gp120 of the human immunodeficiency virus. J. Gen. Virol. 67:2533-2538.

60. Schønning, K., O. Lund, O. S. Lund, and J.-E. S. Hansen. 1999. Stoichiometry of monoclonal antibody neutralization of T-cell line-adapted human immunodeficiency virus type 1. J. Virol. 73:8364-8370.

61. Scott, C. F., Jr., S. Silver, A. T. Profy, S. D. Putney, A. Langlois, K. Weinhold, and J. E. Robinson. 1990. Human monoclonal antibody that recognizes the V3 region of human immunodeficiency virus gp120 and neutralizes the human T-lymphotropic virus type IIIMN strain. Proc. Natl. Acad. Sci. USA 87:8597-8601.

62. Shibata, R., T. Igarashi, N. Haigwood, A. Buckler-White, R. Ogert, W. Ross, R. Willey, M. W. Cho, and M. A. Martin. 1999. Neutralizing antibody directed against the HIV-1 envelope glycoprotein can completely block HIV$1 /$ SIV chimeric virus infections of macaque monkeys. Nat. Med. 5:204-210.

63. Si, Z., N. Phan, E. Kiprilov, and J. Sodroski. 2003. Effects of HIV type 1 envelope glycoprotein proteolytic processing on antigenicity. AIDS Res. Hum. Retrovir. 19:217-226.

64. Sklyanskaya, E. I., M. Shie, Y. S. Komarov, S. S. Yamnikova, and N. V. Kaverin. 1988. Formation of mixed hemagglutinin trimers in the course of double infection with influenza viruses belonging to different subtypes. Virus Res. 10:153-165.

65. Stanfield, R. L., M. K. Gorny, C. Williams, S. Zolla-Pazner, and I. A. Wilson. 2004. Structural rationale for the broad neutralization of HIV-1 by human monoclonal antibody 447-52D. Structure (Cambridge) 12:193-204

66. Starcich, B. R., B. H. Hahn, G. M. Shaw, P. D. McNeely, S. Modrow, H. Wolf, E. S. Parks, W. P. Parks, S. F. Josephs, R. C. Gallo, et al. 1986. Identification and characterization of conserved and variable regions in the envelope gene of HTLV-III/LAV, the retrovirus of AIDS. Cell 45:637-648.

67. Stegmann, T. 2000. Membrane fusion mechanisms: the influenza hemagglutinin paradigm and its implications for intracellular fusion. Traffic 1:598-604.

68. Sullivan, N., Y. Sun, J. Binley, J. Lee, C. F. Barbas III, P. W. Parren, D. R. Burton, and J. Sodroski. 1998. Determinants of human immunodeficiency virus type 1 envelope glycoprotein activation by soluble CD4 and monoclonal antibodies. J. Virol. 72:6332-6338.

69. Taylor, H. P., S. J. Armstrong, and N. J. Dimmock. 1987. Quantitative relationships between an influenza virus and neutralizing antibody. Virology 159:288-298.

70. Taylor, H. P., and N. J. Dimmock. 1994. Competitive binding of neutralizing monoclonal and polyclonal IgG to the HA of influenza A virions in solution: only one IgG molecule is bound per HA trimer regardless of the specificity of the competitor. Virology 205:360-363.

71. Thali, M., J. P. Moore, C. Furman, M. Charles, D. D. Ho, J. Robinson, and J. Sodroski. 1993. Characterization of conserved human immunodeficiency virus type $1 \mathrm{gp} 120$ neutralization epitopes exposed upon gp120-CD4 binding. J. Virol. 67:3978-3988.

72. Thali, M., U. Olshevsky, C. Furman, D. Gabuzda, M. Posner, and J. Sodroski. 1991. Characterization of a discontinuous human immunodeficiency virus type 1 gp120 epitope recognized by a broadly reactive neutralizing human monoclonal antibody. J. Virol. 65:6188-6193.

73. Trkola, A., T. Dragic, J. Arthos, J. M. Binley, W. C. Olson, G. P. Allaway, C. Cheng-Mayer, J. Robinson, P. J. Maddon, and J. P. Moore. 1996. CD4dependent, antibody-sensitive interactions between HIV-1 and its co-receptor CCR-5. Nature 384:184-187.

74. Trkola, A., A. B. Pomales, H. Yuan, B. Korber, P. J. Maddon, G. P. Allaway, H. Katinger, C. F. Barbas III, D. R. Burton, D. D. Ho, and J. P. Moore. 1995 Cross-clade neutralization of primary isolates of human immunodeficiency 
virus type 1 by human monoclonal antibodies and tetrameric CD4-IgG. J. Virol. 69:6609-6617.

75. Trkola, A., M. Purtscher, T. Muster, C. Ballaun, A. Buchacher, N. Sullivan, K. Srinivasan, J. Sodroski, J. P. Moore, and H. Katinger. 1996. Human monoclonal antibody $2 \mathrm{G} 12$ defines a distinctive neutralization epitope on the gp120 glycoprotein of human immunodeficiency virus type 1. J. Virol. 70: 1100-1108.

76. Vancott, T. C., V. R. Polonis, L. D. Loomis, N. L. Michael, P. L. Nara, and D. L. Birx. 1995. Differential role of V3-specific antibodies in neutralization assays involving primary and laboratory-adapted isolates of HIV type 1. AIDS Res. Hum. Retrovir. 11:1379-1391.

77. Verrier, F., A. Nádas, M. K. Gorny, and S. Zolla-Pazner. 2001. Additive effects characterize the interaction of antibodies involved in neutralization of the primary dualtropic human immunodeficiency virus type 1 isolate 89.6. J. Virol. 75:9177-9186.

78. Willey, R. L., J. S. Bonifacino, B. J. Potts, M. A. Martin, and R. D. Klausner. 1988. Biosynthesis, cleavage, and degradation of the human immunodeficiency virus 1 envelope glycoprotein gp160. Proc. Natl. Acad. Sci. USA 85:9580-9584.

79. Wrigley, N. G. 1979. Electron microscopy of influenza virus. Br. Med. Bull 35:35-38.

80. Wyatt, R., P. D. Kwong, E. Desjardins, R. W. Sweet, J. Robinson, W. A
Hendrickson, and J. G. Sodroski. 1998. The antigenic structure of the HIV gp120 envelope glycoprotein. Nature 393:705-711.

81. Wyatt, R., and J. Sodroski. 1998. The HIV-1 envelope glycoproteins: fusogens, antigens, and immunogens. Science 280:1884-1888.

82. Yang, X., R. Wyatt, and J. Sodroski. 2001. Improved elicitation of neutralizing antibodies against primary human immunodeficiency viruses by soluble stabilized envelope glycoprotein trimers. J. Virol. 75:1165-1171.

83. Yuste, E., J. D. Reeves, R. W. Doms, and R. C. Desrosiers. 2004. Modulation of Env content in virions of simian immunodeficiency virus: correlation with cell surface expression and virion infectivity. J. Virol. 78:6775-6785.

84. Zhang, Y. J., R. Fredriksson, J. A. McKeating, and E. M. Fenyo. 1997. Passage of HIV-1 molecular clones into different cell lines confers differential sensitivity to neutralization. Virology 238:254-264.

85. Zhu, P., E. Chertova, J. Bess, Jr., J. D. Lifson, L. O. Arthur, J. Liu, K. A Taylor, and K. H. Roux. 2003. Electron tomography analysis of envelope glycoprotein trimers on HIV and simian immunodeficiency virus virions. Proc. Natl. Acad. Sci. USA 100:15812-15817.

86. Zwick, M. B., M. Wang, P. Poignard, G. Stiegler, H. Katinger, D. R. Burton, and P. W. Parren. 2001. Neutralization synergy of human immunodeficiency virus type 1 primary isolates by cocktails of broadly neutralizing antibodies. J. Virol. 75:12198-12208. 